results are much more easy of attanment when dealing with fresh-water fishes than when dealing with those of the sea. The methods of artificial hatching and rearing have been thoroughly worked out and put into practice, and they are here well described.

The book is profusely illustrated and the illustrations are of such a character that both the interest and the clearness of the descriptions are enhanced.

\section{ECONOMIC ANALYSIS}

(r) Investigating an Industry: a Scientific Diagnosis of the Diseases of Management. By W. Kent. With an Introduction by $\mathrm{H}$. L. Gantt. Pp. xi+x26. (New York: John Wiley and Sons, Inc. ; London : Chapman and Hall, Ltd., I9I4.) Price $4 s .6 d$. net.

(2) Principles of Economics. By Prof. H. R. Seager. Pp. $x x+650$. (London: G. Bell and Sons, Ltd.; New York: H. Holt and Co., 19r3.) Price ros. 6d. net.

(I) $/$ R. KENT'S book belongs to a branch of 1 investigation which has been specially developed in America. It might seem at first that business management scarcely belonged to science, but was rather a question of personal qualification, tact, and resource. When we speak of good management in this country we are inclined to regard it mainly as concerned with labour-saving methods. But this book, and others on the same lines, aim at applying to the faults of business the scientific methods of medical diagnosis; and $\mathrm{Mr}$. Kent has given great vividness to his analysis by working it out in the concrete case of an individual business faced with competition and a falling market. To meet the case, each aspect of organisation, within and without the factory, is examined in detail by an expert. Is the location of the works where it should be, in view of the buying and selling markets, and conditions of transport? Are the buildings well equipped, and are they too large or too small for the most economical output? Is the power plant modern, or does it waste fuel? Are the high-priced men on work which really requires their skiil, or are they being wasted on low-price work? What is the "load-factor" of the machinery-its percentage of running full--both in general and for each machine? How are accounts kept and audited? Are the directors and manager "running full" themselves? An inquisition into each aspect shows, in the case taken, that the main technical fault is the want of a supplementary product to balance fluctuations in the main output, and occupy the spare factory space; while the main defect of organisation is in the work of the direc- tors themselves. The book is full of the keen business spirit of America. Students of scientific economics will be interested to see how, in various detailed ways, the broad principles of the "marginal" method are illustrated.

(2) Prof. Seager has revised and expanded his "Introduction to Economics," and the "Principles" are now a very full treatment of both theory and description. There are also some important historical chapters, so that the book is much wider than its title suggests. In the theoretical chapters, the marginal principle is developed and illustrated with a welcome abundance of comment and illustration. The most interesting, to English readers, of the new chapters are those on social insurance and on profit-sharing; but Prof. Seager is content rather with description here, and some important general questions might have been raised from the point of view of analysis and social ethics. To American readers the chapter on the income tax is appropriate and up to date. It is one of the most valuable of those text-books which are now confirming and establishing the structure of the science.

D. H. M.

\section{OUR BOOKSHELF.}

Geological Map of the Caucasus, with Explanatory Notes. By Dr. F. Oswald. (London: Dulau and Co., Ltd., I9I4.) Price I5s. net.

Dr. Oswald's colour-printed map of the Caucasus is on the scale of $I: x, 000,000$, and covers the country from the Sea of Azov to the Caspian. We may regret that the heights are given in English feet; but those who use it will generally have other topographic maps at hand. It is produced in a bold style, somewhat like that of Noë's map of the Alps, and embodies a good deal of personal study by the author. The descriptive pamphlet directs attention to the production of crystalline schists and the intrusion of granite in pre-Carboniferous times. Intense folding took place in the Upper Jurassic epoch, the pressure acting from the southwest; and the latest and still more important folding, this time induced from the north-east, is of Miocene and even post-Sarmatian age. Kazbek and Elburs are enormous volcanic piles, due to the outwelling of lavas along fractures connected with the final earth-movements of Pliocene times. The author's classification of the Miocene strata brings the Sarmatian into the middle of the system, so that almost all the beds regarded as Miocene in western Europe are crowded into one Lower or Vindobonian series. He retains an Oligocene system, mostly marine, which is well marked off from the prevalent flysch type of Eocene strata.

This work will be of service to many travellers, now that the district is so accessible through Constantinople or Odessa, and it will be of much help to readers of Suess's description of the range. G. A. J. C. No. 2338 , vol. 93] 